\title{
Study on Effectiveness of Ideological and Political Education in Colleges
}

\author{
Jing Chen \\ Nursing School \\ Henan University \\ Kaifeng, Henan, China 475004
}

\begin{abstract}
For long, some certain colleges and universities lack of attention on effectiveness engagement of ideological and political education, which directly affects the effective exertion of ideological and political education. Therefore, in this paper, the author discusses relative issues from the view angle of Effectiveness engagement of ideological and political education in colleges and universities
\end{abstract}

Keywords-colleges and universities; ideological and political; education; effectiveness

\section{INTRODUCTION}

The study on effectiveness engagement of ideological and political education in colleges and universities plays an important role in improving the ideological and political quality of college students. However, the implementation of ideological and political education in colleges and universities at current stage is still not satisfied. Therefore, the effectiveness engagement of ideological and political education in colleges and universities would be taken as the key study content in this paper for discussion.

\section{NECESSITY OF EFFECTIVENESS ENGAGEMENT OF IDEOLOGICAL AND POLITICAL EDUCATION IN COLLEGES AND UNIVERSITIES}

\section{A. It Is the Inevitable Demand of Tendency Change of Both Home and Abroad to Perform Effectiveness of Ideological and Political Education in Colleges and Universities}

Competition among countries is actually the competition of talents. However, talents shall have multiple aspects of quality. Besides certain scientific and cultural knowledge, the ideological quality is also the key composing part of talents. Or it shall be said like this: ideological and moral quality is vital for talents. The lack of ideological quality educating usually indicates direction loss of talents educating. Since the implementation of market economy, various foreign hostile forces have intensified infiltration into ideological field in China. Some certain hostile forces are performing peaceful evolution in China. Such changes bring great challenge to ideological and political education in colleges and universities. Facing to such tendency change, bad ideological and political education would seriously affect the ideological quality educating to college students, which is quite bad for fighting against hostile forces of both home and abroad.

\section{B. It Is the Inevitable Requirement for Higher Education Reform to Exert Effectiveness of Ideological and Political Education}

The objective of higher education report is to promote overall harmonic development of human-beings, which is also the requirement of quality education to talents education. The ideological quality of human is the key composing part of comprehensive quality. And the final objective of higher education is to realize healthy growing of humans. The healthy ideology is the vital condition of physical and psychological health. Therefore, while taking human comprehensive development as the start and end points, the higher education mainly focuses on the educating of ideological and moral quality of college students. The effectiveness engagement of ideological and political education in colleges and universities exerts irreplaceable function in the implementation of higher education and putting the education to college student ideological and moral quality into practice. Therefore, in order to realize higher education reform, it is the inevitable requirement to exert Effectiveness engagement of ideological and political education.

\section{It Is the Inevitable Requirement for Ideological and Political Education Engagement to Exert Effectiveness of Ideological and Political Education}

During the implementation of the ideological and political education, colleges and universities though have done lots of work, they lack of sufficient attention. Since they are still using simple and old measures in the education of this field, they fail to realize the anticipated purpose of education during the practical implementation. Therefore, if the colleges want to reach the education objective, they shall take flexible educational measures and sufficiently exert the effectiveness of the ideological and political education according to the practical status of current stage combing with practical status of college students during the ideological and political education implementation process, thus to promote better progress by effective implementation of ideological and political education. It can be seen that, exertion of effectiveness of ideological and political 
education is the inevitable requirement for engagement of ideological and political education of colleges and universities.

\section{STRATEGIES FOR EFFECTIVENESS ENGAGEMENT OF IDEOLOGICAL AND POLITICAL EDUCATION OF COLLEGES AND UNIVERSITIES}

\section{A. It Shall Strengthen the Leadership of the Party to the Engagement of Ideological and Political Education}

The leadership of the Party is the importance guarantee to the healthy and stable development of socialism career. If the leadership of the Party is lost during the development process of socialism career, the society of China would be a mass everywhere and the nation would surely be enmeshed in misery, just like a hundred years ago. [1:52] In order to get effectiveness, the ideological and political education of college and university students also needs the leadership of the Party. If losing the leadership of the Party, the college student ideological and political education would sure loose the direction and drive, and can hardly realize the effectiveness engagement of college student ideological and political education. Therefore, in specific implementation of ideological and political education of colleges and universities, the leadership of the Party shall be exerted to promote the effectiveness engagement of the ideological and political education of college and university.

\section{B. It Shall Strengthen the Construction of Ideological and Political Education Faculty}

For long, colleges and universities lack of attention on ideological and political subject, and consider that such education has no big help in the employment of students or less importance than those professional courses having close relation with future employment. Under the leadership of such thoughts, some certain colleges and universities lack of attention on the faculty construction of ideological and political education. And under the condition of lack of attention, the teachers engaging in ideological and political education would hardly work wholeheartedly in ideological and political education and teaching. They fail to update knowledge or follow new changes and tendency of education in that filed, so that they need for further improvement in both the working consciousness and attitude, and professional level. Facing to such situation, the colleges and universities shall pay great attention to the ideological and political teacher team construction, strengthen professional training on them, thus to improve their quality and promote effective engagement of ideological and political education of colleges and universities.

\section{It Shall Enrich the Contents of Ideological snd Political Education}

Traditional ideological and political education contents are featured in more theoretical contents, less practice contents, and less connection to practical students' ideology. Such kind of contents lacks of attraction to students. And the students are not willing or lack of passion to participate into such ideological and political education activity. This is bad for the effectiveness engagement of ideological and political education of colleges and universities. Therefore, in order to change such education status, it needs to be bond in making optimization to currently existing contents of ideological and political education in colleges and universities, selecting the contents having effectiveness, and carrying out relative activities to better promote the exertion of effectiveness of ideological and political education by such rich contents

\section{CONCLUSION}

Study on effectiveness engagement of ideological and political education in colleges and universities has great importance on promotion of effective implementation of ideological and political education of colleges and universities. And currently, the ideological and political education of colleges and universities still has lots of problems. Therefore, it is necessary to make clear about the existing problems and proposing settlement strategies towards effectiveness.

\section{REFERENCES}

[1] Luo Hongtie Special Study on Ideological and Political Education [M] Beijing, Central Party Literature Press, 2012:51-53 